\title{
Methods to analyze spatio-temporal rainfall variability: application to the Pajeú river basin, Pernambuco
}

Método de análise da variabilidade espaço-temporal da precipitação: aplicação na bacia hidrográfica do rio Pajeú-Pernambuco



\section{A B S T R A C T}

This paper addresses a methodology for analyzing spatio-temporal rainfall variability as a tool to support action planning that could mitigate negative impacts and reduce conflicts over water use in the Pajeú river basin, located in the semi-arid region of the state of Pernambuco. We used daily rainfall data from 11 rainfall stations, between 1964 and 2016, provided by the Pernambuco Water and Climate Agency (Agência Pernambucana de Águas e Clima - APAC) and the National Water Agency (Agência Nacional de Águas - ANA). This analysis employed the RClimDex software to calculate rainfallrelated climate extremes indices, aiming at monitoring and detecting climate changes and alterations in the regional rainfall pattern. The results indicated a change in the rainfall pattern in the Pajeú river basin, and all climate indices obtained converge toward the increase in water scarcity in the area, contributing to the recurrent droughts that impact the region.

Keywords: RClimDex; climate change; semi-arid.

\section{RE S U M 0}

Este artigo aborda uma metodologia de análise da variabilidade espaçotemporal da precipitação como ferramenta para subsidiar o planejamento de ações que venham a mitigar os impactos negativos e reduzir os conflitos pelo uso da água na bacia hidrográfica do rio Pajeú, localizada na porção semiárida do estado de Pernambuco. Foram utilizados dados diários de precipitação de 11 postos pluviométricos, no período de 1964 a 2016, fornecidos pela Agência Pernambucana de Águas e Clima (APAC) e pela Agência Nacional de Águas (ANA). Para esta análise, utilizou-se o software RClimDex para calcular os índices de extremos climáticos provenientes de precipitação pluviométrica, visando monitorar e detectar as mudanças do clima e a alteração do padrão pluviométrico da região. Os resultados indicaram modificação no padrão pluviométrico na bacia do Pajeú, e todos os índices climáticos calculados convergem para o aumento da escassez hídrica na região, contribuindo para as recorrentes secas que abalam a região.

Palavras-chave: RClimDex; mudanças climáticas; semiárido.

\footnotetext{
${ }^{1}$ Universidade Federal de Pernambuco - Recife (PE), Brazil.

${ }^{2}$ Universidade Federal do Agreste - Garanhuns (PE), Brazil.

Correspondence address: Maria do Carmo Martins Sobral - Centro de Tecnologia e Geociências - Avenida da Arquitetura, s/n. - Cidade Universitária - CEP: 50740-550 - Recife (PE), Brazil. E-mail: maria.msobral@ufpe.br

Conflicts of interest: the authors declare that there are no conflicts of interest.
}

Funding: none.

Received on: 07/15/2020. Accepted on: 03/09/2021.

https://doi.org/10.5327/Z21769478866 


\section{Introduction}

Climate change has increased water stress in several river basins in Brazil and in the world, leading to greater pressure for water resources management, especially in low rainfall areas, such as the Brazilian Northeast semi-arid region. According to studies by the Brazilian Panel on Climate Change (PBMC, 2014), this region is one of the most vulnerable to the impacts of climate change in Latin America (Marengo et al., 2018; Silva et al., 2020). Bork et al. (2017) state that most studies on climate change assessing certain Brazilian locations show an increasing trend in extreme events throughout this century compared to the climate of the last century. Such a finding allows predicting severe drought or heavy rainfall problems in the future.

For Grassi et al. (2013) and Zhang et al. (2014), extreme climate events are directly related to climate change, inducing hydrological and thermal anomalies, which affect the livelihood of the population and modify existing relationships.

In addition to climate factors, the semi-arid region of the Northeast negatively stands out for its high rates of socioeconomic vulnerability and low human development index due to the great poverty in the area, increasing the migration potential (Nobre et al., 2019; Galvão et al., 2020).

Moreover, agriculture is a very common economic practice in the region, especially dryland farming (Lemos and Santiago, 2020), which, given the low investments in agricultural techniques, completely relies on the availability of natural resources, thus suffering with potentially negative impacts on water resources and compromising the economy and quality of life of the local population (Huang et al., 2016).

Regarding future scenarios, projections by the Fifth Assessment Report of the Intergovernmental Panel on Climate Change (IPCC, 2014) indicate an increase in the frequency of extreme events in semi-arid regions of the planet, causing longer droughts as a consequence of the reduced rainfall, as well as the rise in temperatures in the upcoming decades. As a result, evapotranspiration will increase, while water availability will decrease (Sobral et al., 2018; Cardoso et al., 2019; Santos et al., 2019). IPCC's Fifth Assessment Report also showed that extreme climate events are associated with increased frequency, severity, and duration of precipitation (Seley et al., 2014; Yilmaz et al., 2014).

According to the Report of the Brazilian Panel on Climate Change (PBMC, 2013), the Northeastern semi-arid region will likely have its rainfall reduced by up to $20 \%$ by 2040 . This report also indicates that Brazil should become at least $3^{\circ} \mathrm{C}$ warmer by the end of the century, and rainfall might increase, on average, by $30 \%$ in the South and Southeast regions and decrease by up to $40 \%$ in the North and Northeast regions (Souza et al., 2018).

These PBMC percentages are climate prognoses estimated in mean values based on IPCC optimistic and pessimistic scenarios, which point to an increase of $1-3^{\circ} \mathrm{C}$ and $2-4^{\circ} \mathrm{C}$, respectively (Montenegro et al., 2010; Cavalcante Junior et al., 2016).
This paper aims to present a method to analyze spatio-temporal rainfall variability in the Pajeú river basin as a tool to support action planning that could mitigate negative impacts and reduce conflicts over water use.

\section{Method}

\section{Study area}

The selected study area was the Pajeú river basin, located in the Sertão of Pernambuco State, a semi-arid region of the Brazilian Northeast. It is located between the coordinates $07^{\circ} 16^{\prime} 20^{\prime \prime}$ and $08^{\circ} 56^{\prime} 01^{\prime \prime} \mathrm{S}$ and $36^{\circ} 59^{\prime} 00^{\prime \prime}$ and $38^{\circ} 57^{\prime} 45^{\prime \prime} \mathrm{W}$, specifically in the Pernambuco Sertão and São Francisco mesoregions.

The Pajeú river basin covers 27 municipalities, 16 of them completely within the basin area. It involves all Pajeú microregions and part of the Sertão of Moxotó, Salgueiro, and Itaparica. It has an area of $16,685.63 \mathrm{~km}^{2}$, that is, $16.9 \%$ of the total area of Pernambuco, making it the largest river basin of the state in territorial extension (Figure 1).

From a climate perspective, the basin area is characterized by very irregular rainfall, with January to April as the main rainy season. Sertão rains originate from cold fronts, upper tropospheric cyclonic vortices (UTCV), and the intertropical convergence zone (ITCZ). The last one is the main rainfall production system in the Pernambuco semi-arid region (Pernambuco, 2006).

In the Pernambuco Sertão, rainfall starts in December (extreme west) and is associated with cold front instabilities and UTCV. As of February or March, depending on the year, ITCZ begins to act throughout the Sertão, which is already in its main rainy season.

Total annual precipitation usually fluctuates between 400 and $1,200 \mathrm{~mm}$. The dry season can last from 7 to 10 months, and semi-aridity is very pronounced in the lower region, near the São Francisco River, where total annual values often range from 400 to $500 \mathrm{~mm}$. Rainfall increases in the north, reaching averages between 700 and $800 \mathrm{~mm}$.

We selected the Pajeú river basin as a case study for this statistical method of precipitation analysis due to its economic and social relevance in the semi-arid region of Pernambuco, besides it being the largest basin of the state in territorial extension. Thus, we emphasize the importance of implementing this methodology, using river basins as a planning unit to design short- and medium-term actions.

\section{Data acquisition and analysis}

This work assessed 52 years of daily rainfall data - 1964 to 2016 . Data were collected from the Pernambuco Water and Climate Agency (Agência Pernambucana de Águas e Clima - APAC), through its online database (APAC, 2021), and the National Water Agency (Agência Nacional de Águas - ANA), from its hydrologic information system (HIDROWEB) (ANA, 2021).

Among the rainfall stations located in the Pajeú river basin, 11 were selected for their good data quality and homogeneity, with few issues, and for representing a satisfactory spatial distribution of the whole basin (Figure 2). 



Figure 1 - Spatial location of the Pajeú river basin.

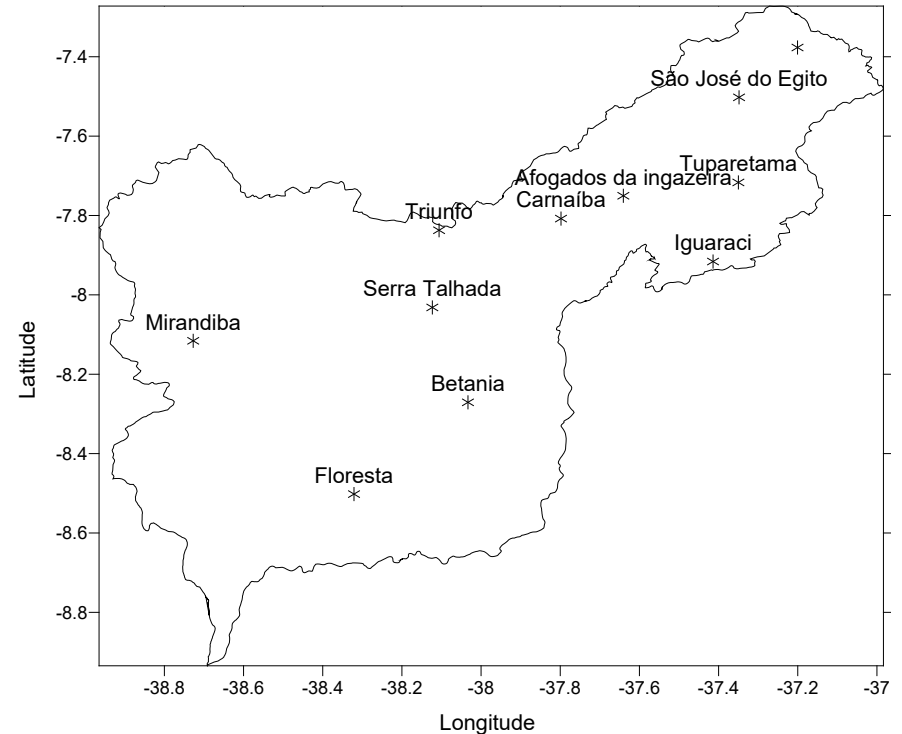

Figure 2 - Spatial distribution of rainfall stations in the Pajeú river basin.

\section{Evaluation of climate extremes indices}

We used the RClimDex software, version 3.2.1, to identify trends in climate extremes indices. Recommended by the World Meteorological Organization (WMO), the software calculates climate extremes indices to monitor and detect climate changes. It was developed by Byron Gleason, a researcher at the National Climatic Data Center (NCDC) of the National Oceanic and Atmospheric Administration (NOAA). This software is available for free on the Expert Team on Climate Change Detection, Monitoring and Indices (ETCCDMI) website (http://cccma.seos.uvic.ca/ETCCDMI).

RClimDex 3.2.1 calculates all 27 basic indices (11 related to precipitation and 16 to temperature) recommended by the ETCCDMI and provides statistical information for each index, including: linear trend calculated by the least-squares method, statistical significance of the trend (p-value), coefficient of determination $\left(\mathrm{R}^{2}\right)$, and standard error of estimate, in addition to annual time-series graphs. The software was used to obtain all rainfall-related climate indices, whose values are listed in Table 1. 
Table 1 - Climate indices related to daily rainfall with definitions and units.

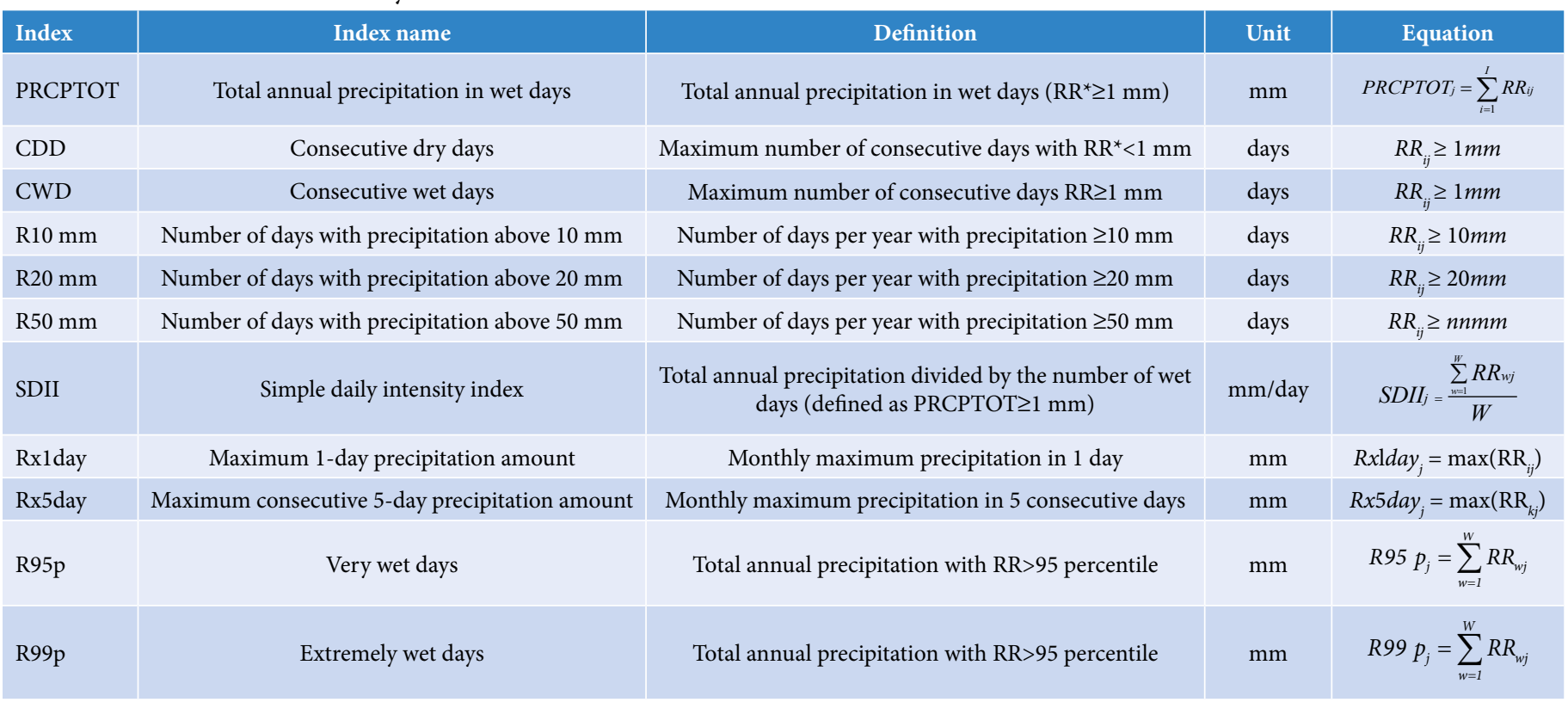

${ }^{*}$ RR: daily rainfall rate.

Source: RClimDex (2004).

The climate indices described above generate annual time series graphs composed of trends and calculated by the least-squares linear regression method, with statistical significance, showing the adjustments of these linear trends for the graphs.

Data quality control is a prerequisite for calculating indices using the RClimDex 3.2.1 software and consists of the following procedures:

- replace all missing values (which must already be coded as -99.9)

for internal formats recognized by $\mathrm{R}$ (i.e., declares them as not available);

- replace all unacceptable data matrix values by -99.9, including precipitation values less than zero (notably absurd).

The p-value calculated by Student's $t$-test represents the level of statistical significance. If the p-value of any index is equal to or less than 0.1 , the index trend is statistically significant at $90 \%$; if it is equal to or less than 0.05 , the statistical significance is at $95 \%$, and p-values less than 0.01 show a trend with statistical significance at $99 \%$.

This study adopted Student's $t$-test because it is one of the most widely used distributions in statistics, with applications ranging from statistical modeling to hypothesis testing. Other methods could also be used, such as Mann-Kendall, linear regression, and Pettitt parametric tests; however, the RClimDex software employs Student's $t$-test in its operational package.

The present investigation used this test to evaluate whether the trend values obtained were significant or not. Student's $t$-test is one of the most widely used distributions for small samples and in meteorological studies (Kousky and Kayano, 1994; Kayano and Kousky, 1996; Castro, 2002; Silva and Sousa, 2013). It can be calculated by Equation 1:

$\mathrm{tc}=\mathrm{t} / \sqrt{ }((\mathrm{n}-2)+\mathrm{t} \wedge 2)$

In which:

tc = percentile value;

$c=$ degree of freedom - we used $=95$ or $95 \%$;

$\mathrm{t}=$ percentile value.

Maps were generated with the calculated climate index data using the Golden Software Surfer, which allows complete visualization of the spatial behavior of the studied variable. We adopted the kriging method, which is based on data interpolation, obtained using tabular data and geographic location. In kriging, intermediate data values are preserved, and the result is a continuous surface of smoother data, minimizing the contrasts between polygons. Kriging uses mathematical functions to add larger weights in positions closest to the sampling points and lower weights in the farthest positions, thus creating new interpolated points based on these linear data combinations (Viola et al., 2010).

After the spatial trend analysis of climate extremes indices, we performed a time analysis of each index to have an overview of the 
interannual climate variability throughout the Pajeú river basin. To this end, we calculated the weighted average of the basin with the Thiessen method.

\section{Results and Discussion}

The analysis of spatio-temporal rainfall variability in the Pajeú river basin showed a significant change in precipitation pattern and behavior throughout the study site. Over the 52 years analyzed, we could identify both the decrease in total annual precipitation and the increase in consecutive days without rainfall, a situation that converges toward a state of water scarcity in the region. In addition to reduced precipitation and increased dry days, we found a decreasing trend in daily rainfall intensity and number of days with moderate and strong rainfall.

Table 2 describes the trend values of climate extremes indices calculated based on rainfall data from the Pajeú river basin, covering the period between January 1964 and December 2016.

Values highlighted in gray are statistically significant; those in gray and italics have $\mathrm{p}<0.1$; those in gray and bold have $\mathrm{p}<0.05$.

Values without a gray background in the table presented $\mathrm{p}>1$ and no statistical significance, as their reliability was below $90 \%$. As a result, they were not considered in the analyses, since it is not safe to state that they are actual trends.

Table 2 shows that, among all indices calculated, those with the highest number of statistically significant results were the total annual precipitation index (PRCPTOT) and the number of days with rain above 10 and $20 \mathrm{~mm}$ (R10 $\mathrm{mm}$ and R20 $\mathrm{mm}$, respectively).

\section{Total annual precipitation analysis}

First, the PRCPTOT analysis revealed a marked decrease in precipitation, detected in all municipalities that presented statistical significance.
According to this result, the study area showed a rainfall reduction ranging from $107.6 \mathrm{~mm}$ to $380.5 \mathrm{~mm}$ in the 52 years analyzed. The municipality of Floresta had the lowest rainfall reduction, with a rate of $-2.07 \mathrm{~mm} /$ year, while Carnaíba presented the highest rainfall decrease, with a rate of $-7.61 \mathrm{~mm} /$ year, as shown in Figure 3.

Figure 3 also demonstrates that the lowest rainfall reduction occurred in the southern part of the basin, which is closer to the São Francisco River and has the highest semi-aridity index according to the climate classification of the basin. The rainfall reduction in the study area over 52 years corroborates the history of water scarcity that has been affecting the semi-arid region of the Brazilian Northeast, which currently faces the most severe drought in recent decades.

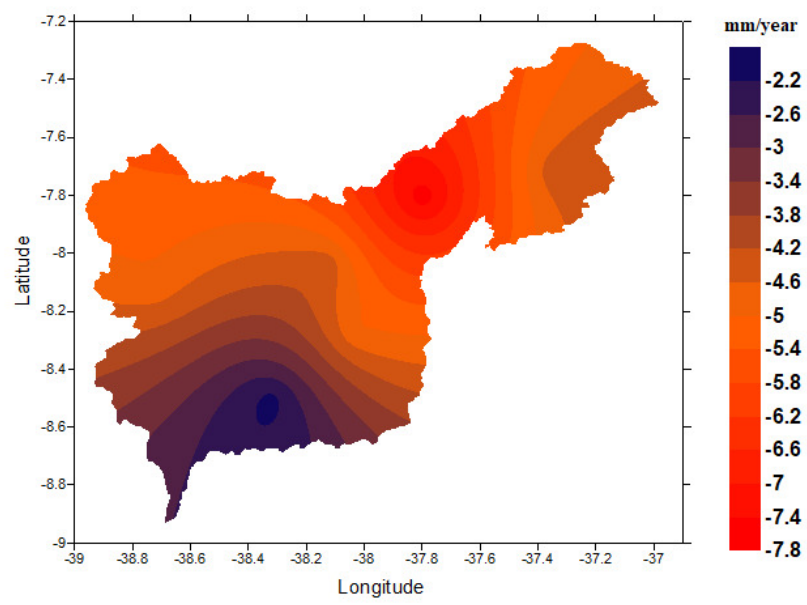

Figure 3 - Spatial distribution of total annual precipitation in the Pajeú river basin from 1964 to 2016 .

Table 2 - Trends in rainfall-related climate extremes indices for 11 municipalities along the Pajeú river basin.

\begin{tabular}{|c|c|c|c|c|c|c|c|c|c|c|c|}
\hline & $\begin{array}{l}\text { PRCPTOT } \\
(\mathrm{mm})\end{array}$ & $\begin{array}{c}\text { CDD } \\
\text { (days) }\end{array}$ & $\begin{array}{l}\text { CWD } \\
\text { (days) }\end{array}$ & $\begin{array}{c}\text { R10mm } \\
\text { (days) }\end{array}$ & $\begin{array}{c}\text { R20mm } \\
\text { (days) }\end{array}$ & $\begin{array}{c}\text { R50mm } \\
\text { (days) }\end{array}$ & $\underset{(\mathrm{mm} / \text { day })}{\text { SDII }}$ & $\begin{array}{l}\text { Rx1day } \\
(\mathrm{mm})\end{array}$ & $\begin{array}{c}\text { Rx5day } \\
(\mathrm{mm})\end{array}$ & $\begin{array}{l}\text { R95p } \\
(\mathrm{mm})\end{array}$ & $\begin{array}{l}\text { R99p } \\
(\mathrm{mm})\end{array}$ \\
\hline Afogados da Ingazeira & 0.906 & 0.345 & -0.03 & 0.072 & 0.029 & 0.012 & 0.085 & 0.225 & 0.458 & 1.392 & 0.504 \\
\hline Carnaíba & -7.617 & -0.987 & 0.009 & -0.328 & -0.175 & 0.006 & -0.15 & 0.167 & -0.895 & 0.085 & 0.782 \\
\hline Floresta & -2.073 & 0.002 & -0.027 & -0.103 & -0.039 & -0.016 & -0.183 & -0.08 & -0.446 & -1.231 & 0.51 \\
\hline Mirandiba & -4.885 & -0.074 & -0.056 & -0.177 & -0.09 & -0.046 & -0.181 & -0.388 & -0.473 & -1.523 & -0.231 \\
\hline São José do Egito & -2.37 & -0.299 & -0.002 & -0.109 & -0.07 & -0.002 & 0.019 & 0.112 & -0.328 & -0.055 & -0.175 \\
\hline Serra Talhada & -4.398 & 0.525 & -0.009 & -0.126 & -0.031 & -0.018 & 0.022 & 0.021 & -0.298 & -1.291 & -0.201 \\
\hline Triunfo & -5.321 & 0.703 & -0.057 & -0.164 & -0.096 & 0.003 & 0.037 & -0.302 & -0.472 & -0.295 & -0.479 \\
\hline
\end{tabular}


Considering that the historical average rainfall of the Brazilian Northeast semi-arid region, particularly of the Pajeú river basin, ranges from 400 to $800 \mathrm{~mm}$ a year, we found a loss of approximately a whole year of precipitation during these 52 years (1964-2016), a situation that tends to worsen if this scenario becomes a reality. This rainfall variation in the region can be attributed to large-scale circulation, while rainfall intensity might influence climate variability.

Similar results were found by Assis (2016) in an analysis of the São Francisco river basin, in the Submédio stretch, which covers part of the Pernambuco semi-arid region and part of mid-northern Bahia, where even higher decreasing trends in rainfall have been detected, reaching approximately $14 \mathrm{~mm} /$ year in the Araripina microregion.

The study evidenced the need to deepen the analysis of climate extremes indices, given the economic, political, and social importance of the Pajeú river basin to the state, as it is the largest basin of Pernambuco. The Pajeú River is the largest tributary of the São Francisco River, and its basin extends across important municipalities whose economy relies on agriculture, both irrigated and dryland farming - the latter completely dependent on climatic factors.

Moncunill (2006) conducted a study in Ceará and also found negative trends in annual precipitation between 1974 and 2003. We underline that few studies in Northeastern Brazil use this methodology, which is more concentrated and widespread in the South, Southeast, and Midwest regions of Brazil, as well as other South American countries.

The Brazilian semi-arid region is not the only one experiencing an increase in water scarcity. Vargas-Amelin and Pindado (2014) investigated the Mediterranean region of Spain, also characterized by a semi-arid climate, and found a decrease in rainfall when analyzing a 70 -year period (1940 to 2010).

Figure 4 shows the linear trend calculated for total annual precipitation, also from 1964 to 2016. This analysis revealed that, in most years, the total annual precipitation was below the trend line, that is, over these 52 years, rainfall gradually remained below the historical average rainfall for the region.

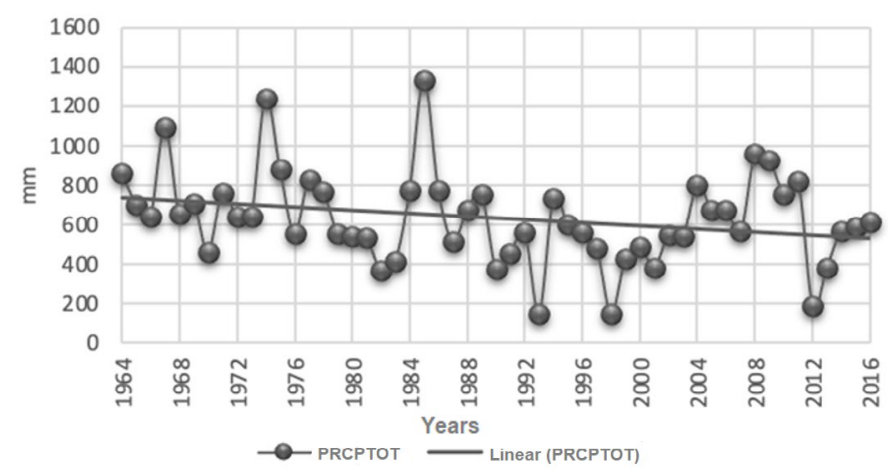

Figure 4 - Linear trend of total annual precipitation in the Pajeú river basin from 1964 to 2016.
Total annual precipitation reached its highest values in 1967, 1974, and 1985. These results are a consequence of strong and moderate La Niña events, which contributed to the higher total rainfall in these years. On the other hand, years with total annual precipitation below the historical average were more prevalent, with a gradually decreasing trend in these rainfall values. As shown in the graph in Figure 4, 1993, 1998, and 2012 stand out for having the lowest total annual precipitation values, not reaching $200 \mathrm{~mm}$ /year. 1993 and 1998 are associated with strong El Niño events, inhibiting rainfall in Northeastern Brazil. Despite the lack of El Niño events, 2012 was an extremely dry year due to acting systems and sea surface temperature anomaly (SSTA).

Another important factor in the time trend analysis of the total annual precipitation index is that rainy years, with annual rainfall above average, occurred mainly until the late 1980s, with a predominance of dry years thereafter. This rainfall pattern change in the Pajeú river basin demonstrates a possible climate variation. This detailed analysis is made separately for each year in the following sub-section, which addresses the rainfall anomaly index.

\section{Analysis of consecutive dry and wet days}

According to Table 2, the analysis of the indices number of consecutive dry days (CDD) and maximum number of days with precipitation above $1 \mathrm{~mm}$ (consecutive wet days - CWD) shows an increasing trend in dry days and consequent decrease in rainy days among the municipalities that presented statistical significance. These indices are inversely proportional and complementary.

CDD variation fluctuated between 0.34 days/year and 0.70 days/ year in Afogados da Ingazeira and Triunfo, respectively. Namely, Triunfo, which stands out from other municipalities for its local microclimate and higher annual rainfall rates, also has the highest trend in consecutive days without rain.

Triunfo did not show statistical significance in the total annual precipitation index, so we can state that, in addition to the higher number of dry days, the city might also be experiencing a gradual decrease in precipitation. CWD variation ranged from -0.02 (Floresta) to -0.05 (Triunfo).

Although not high, the CDD and CWD trend variation is significant since the Pajeú river basin already shows a reduction in its annual rainfall. Figure 5 depicts the CDD and CWD spatial distribution.

The time analysis of these indices reveals that some years reach 120 CDDs. Once more, 1993, 1998, and 2012 stand out since these years had the longest dry period in addition to the highest annual rainfall reduction. In a similar study, but that calculated the rainfall anomaly index, Assis et al. (2015) also identified 1993, 1998, and 2012 as the driest years of the whole series of data studied (1964-2014) for river basins in the Pernambuco semi-arid region.

The graph showing the number of CWDs indicates a decreasing time trend, that is, increasingly fewer successive rainy days. Again, 1993, 1998, and 2012 stand out, this time for having less 


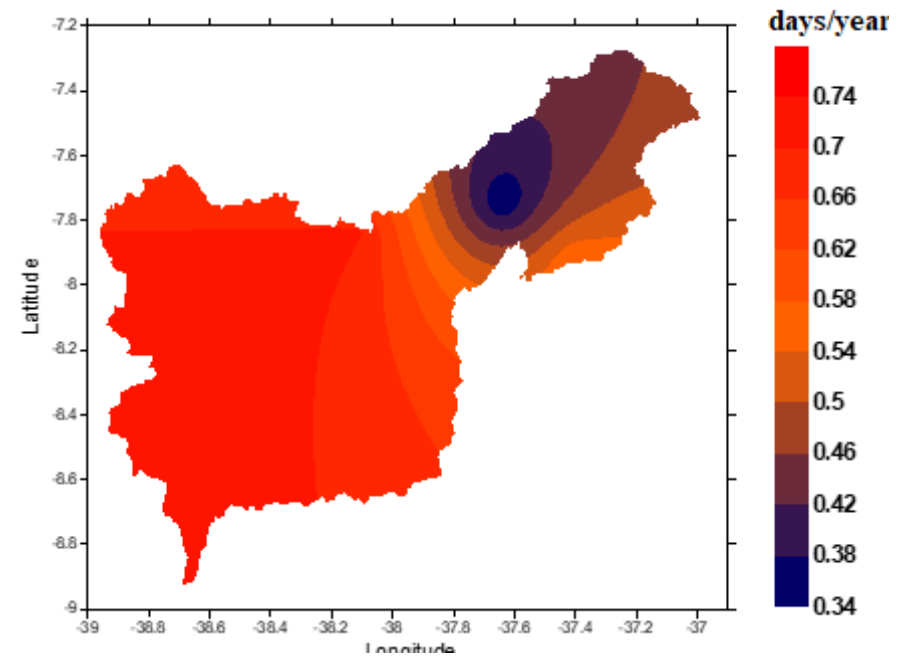

(a)

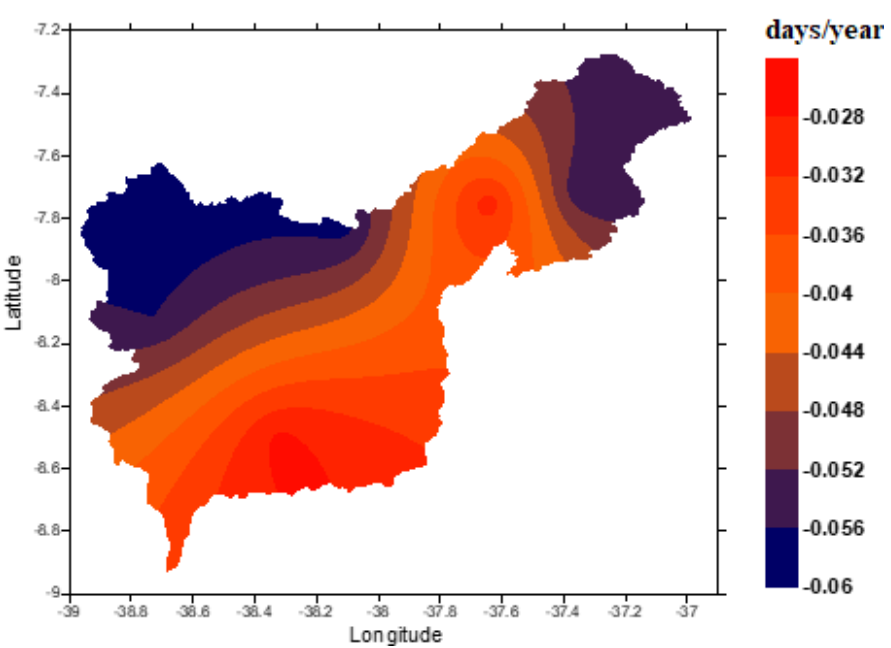

(b)

Figure 5 - (A) Spatial distribution of the number of consecutive dry days and (B) consecutive wet days (rain $>1$ mm) in the Pajeú river basin in days/year (1964-2016).

than five CWDs per year. The CDD increase and CWS decrease mean not only less rain in the study area, as evidenced by the PRCPTOT index, but the progressive concentration of rains in a shorter interval.

Nóbrega (2010) analyzed 35 rainfall stations in the Sertão of Pernambuco and found similar results, indicating a higher number of dry days in the rainy season. Nóbrega et al. (2015) investigated the entire state of Pernambuco from 1978 to 2010 using the same methodology for the assessment of climate extremes indices, concluding that rains are becoming increasingly concentrated in a few days over the year in the Sertão and Agreste of Pernambuco. Sertão also had the highest numbers and extremely dry spells. Figure 6 illustrates the CDD and CWD time trends.

\section{Analysis of days with strong and moderate precipitation}

The analysis of $\mathrm{R} 10 \mathrm{~mm}, \mathrm{R} 20 \mathrm{~mm}$, and $\mathrm{R} 50 \mathrm{~mm}$ points to negative trends in all indices, that is, a reduction in days with rain above $10 \mathrm{~mm}$, $20 \mathrm{~mm}$, and $50 \mathrm{~mm}$ per year.

These indices are directly proportional to total annual precipitation and CDD since, when annual rainfall decreases and the number of dry days increases, rainfall becomes less intense; thus, days with moderate $(10 \mathrm{~mm}$ and $20 \mathrm{~mm})$ and strong $(50 \mathrm{~mm})$ rains are increasingly sporadic.

Comparing the results of Table 2 , the $\mathrm{R} 10 \mathrm{~mm}$ index ranges from -0.10 days/year to -0.33 days/year in Floresta and Tuparetama, respectively. The $\mathrm{R} 20 \mathrm{~mm}$ index varies from -0.06 days/year (Betânia) to -0.175 (Carnaíba). In turn, the $\mathrm{R} 50 \mathrm{~mm}$ index ranges from - 0.002 days/year to -0.046 days/year in Floresta and Mirandi- ba, respectively. Figure 7 shows the spatial distribution of R10 mm, $\mathrm{R} 20 \mathrm{~mm}$, and $\mathrm{R} 50 \mathrm{~mm}$.

The time trend of the $\mathrm{R} 10 \mathrm{~mm}$ index reveals a decreasing line, with 1974 and 1985 standing out with the highest peaks. Therefore, these years had more days with precipitation equal to or above $10 \mathrm{~mm}$. The region had approximately 40 days of moderate rainfall in 1974 and around 50 days in 1985.

1974 and 1985, which presented the greatest number of days with moderate rainfall, also had the highest total rainfall in the calculation of the PRCPTOT index. On the other hand, 1993 and 1998 showed the lowest number of days with moderate rainfall, not exceeding the fiveday range. We highlight that these years also presented the lowest total annual precipitation in the PRCPTOT index. This finding shows the proportion between the index calculations, which are complementary.

As in the R10 mm index, the linear trend of the R20 mm index was negative, indicating a lower number of days with precipitation above $20 \mathrm{~mm}$. The highest peaks occurred in 1967, 1974, and 1985, with approximately 15 days of moderate rainfall.

According to the PRCPTOT index, these same years showed higher total annual precipitation. After calculation of the weighted average for the time analysis, the R50 $\mathrm{mm}$ index showed no noticeable trend and thus was not considered for this analysis. Figure 8 presents the linear time trend graphs of the $\mathrm{R} 10 \mathrm{~mm}$ and $\mathrm{R} 20 \mathrm{~mm}$ indices.

\section{Daily rainfall intensity analysis}

The simple daily intensity index (SDII), which represents the daily rainfall intensity and results from the proportion between total annual 

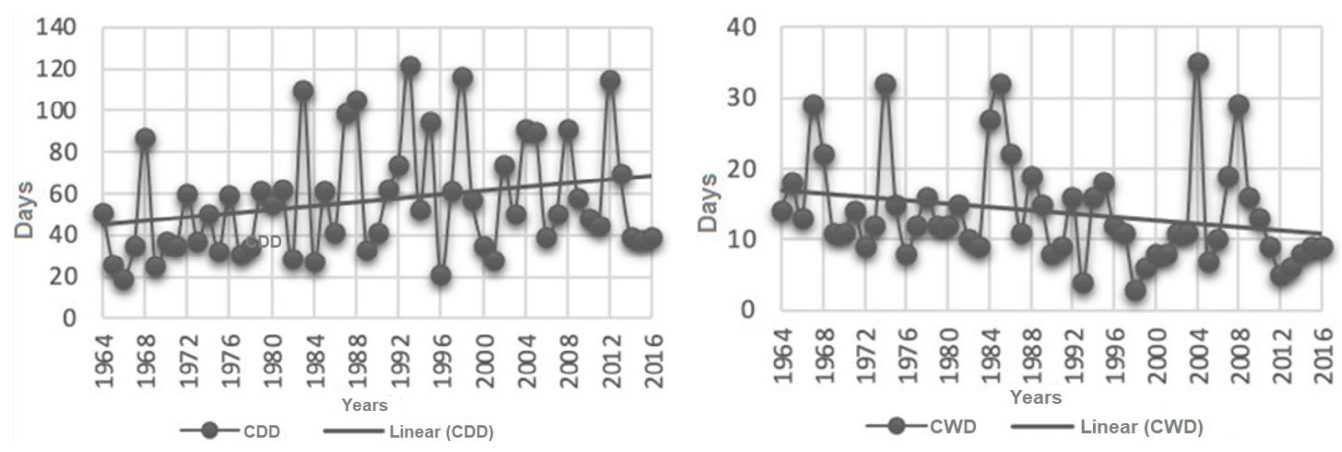

Figure 6 - (A) Linear trend of the number of consecutive dry days and (B) number of consecutive wet days (rain $>1$ mm) in the Pajeú river basin in days/year (1964-2016).


Figure 7 - Spatial distribution map of the climate indices (A) R10 mm, (B) R20 mm, and (C) R50 mm in the Pajeú river basin in days/year (1964-2016).

precipitation and the number of rainy days, presented both positive and negative trends. However, municipalities with statistical significance showed a prevalence of negative trends, with a decrease in daily rainfall intensity; only one city had a positive trend for this index - Afogados da Ingazeira, with a value of $0.085 \mathrm{~mm} /$ day. Regarding negative indices, Tuparetama stood out, with $-0.211 \mathrm{~mm} /$ day, as seen in Table 2.

Municipalities with a decrease in daily rainfall intensity also had a reduction in total annual precipitation. The only municipality with an upward trend in daily rainfall intensity also experienced an increase in total annual precipitation, albeit without statistical significance.

Similar results were found by Silva et al. (2012) in a study of the state of Bahia from 1970 to 2006, which assessed climate change detection indices. They identified a downward trend in daily rainfall intensity and total annual precipitation in the Baixo São Francisco region. According to the authors, this rainfall variation can be attributed to large-scale circulation, while rainfall intensity might influence climate variability. 

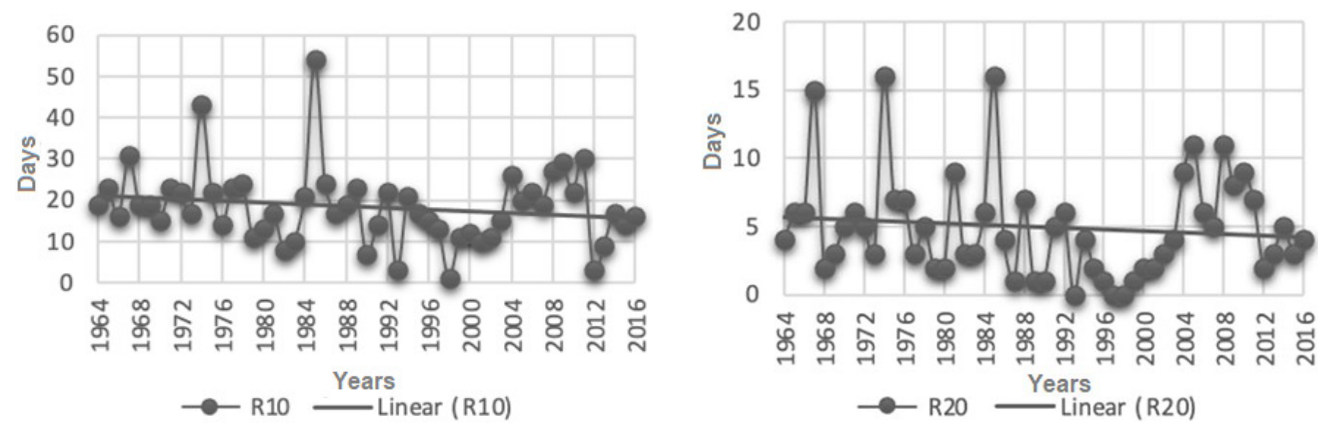

Figure 8 - (A) Linear trend of the number of days/year with precipitation $\geq 10 \mathrm{~mm}-\mathrm{R} 10 \mathrm{~mm}$ and $(\mathrm{B}) \geq 20 \mathrm{~mm}-\mathrm{R20} \mathrm{mm}$ in the Pajeú river basin (19642016).

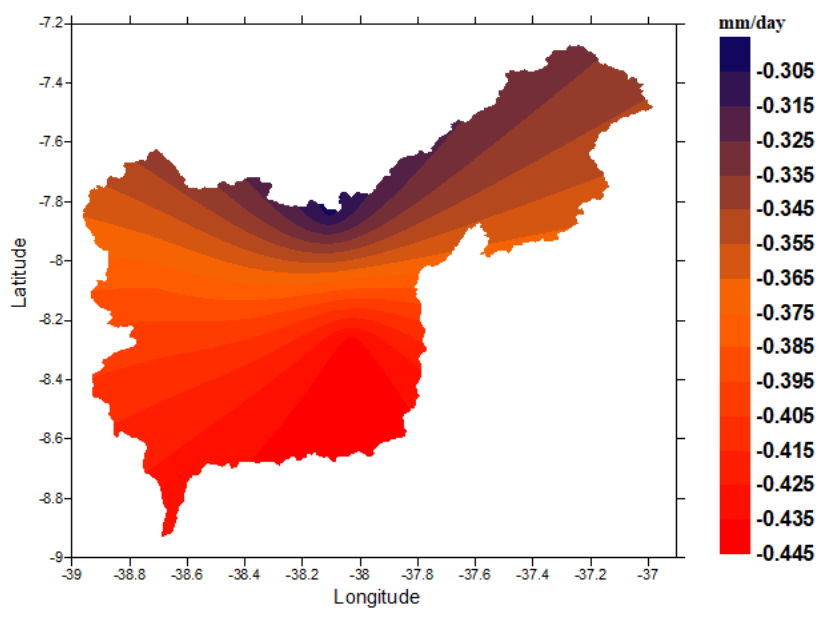

Figure 9 - Spatial distribution map of the simple daily intensity index in the Pajeú river basin in $\mathrm{mm} /$ day (1964-2016).

Figure 9 depicts the SDII spatial distribution, which clearly evidences a decrease in daily rainfall intensity throughout the basin, except for Afogados da Ingazeira, in the northernmost part of the basin, which presents an increase in the daily rainfall intensity index.

The time analysis of the daily rainfall intensity index showed no trend, as, after the calculation of the weighted average, heavy rains are distributed to other rainfall stations; thus, the average value does not represent the reality of each municipality.

\section{Monthly maximum precipitation analysis}

The Rx1day and Rx5day indices, which correspond to the maximum 1-day and consecutive 5-day precipitation amount, presented a statistically significant trend in few municipalities, three for the Rxlday index and two for the Rx5day index. Nonetheless, both showed negative trends, converging toward a decrease in Rxlday

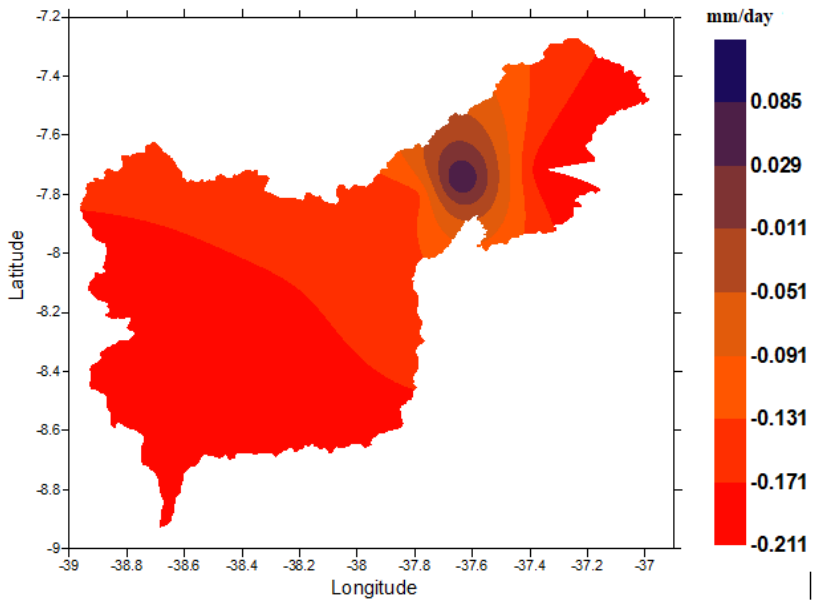

Figure 10 - Spatial distribution map of the Rx1day index in the Pajeú river basin in $\mathrm{mm} /$ day (1964-2016).

and Rx5day. This result is complementary to the total annual precipitation index since as total annual precipitation decreases, so does the precipitation amount in one and five consecutive days. The Rxlday index ranges from -0.302 in Triunfo to $-0.439 \mathrm{~mm} /$ day in Betânia.

Figure 10 demonstrates the Rx1day spatial distribution, indicating a gradual daily rainfall intensity, decreasing as it approaches the southern part of the basin, which is closer to the São Francisco River and classified as the most semi-arid area of the Pajeú river basin. Since the Rx5day index presented statistical significance in only two municipalities, we could not interpolate the values in the map.

Concerning time trends, the Rx1day and Rx5day indices present the monthly maximum 1-day and consecutive 5-day precipitation amounts. The results displayed in the graph correspond to the month (in one year) with the highest precipitation value in $\mathrm{mm}$ for the period (one day/five days). 


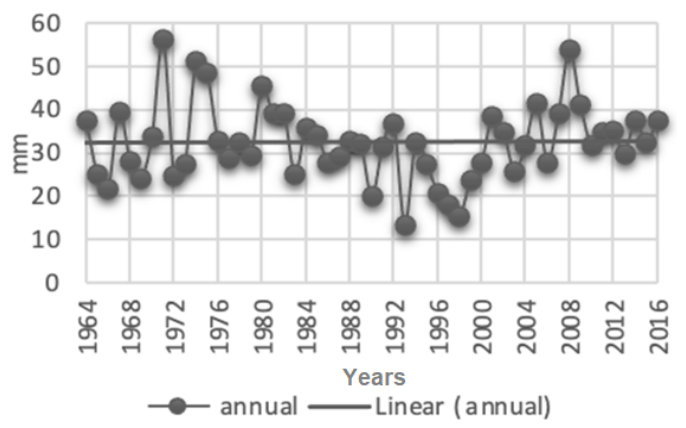

(a)

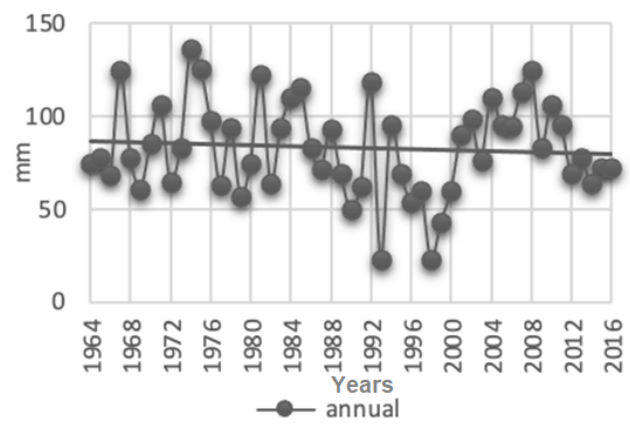

(b)

Figure 11 - Linear trend of monthly maximum 1-day precipitation - Rx1day and monthly maximum consecutive 5-day precipitation - Rx5day in the Pajeú river basin in $\mathrm{mm} /$ year (1964-2016).

As shown in Figure 11, the Rx1day index did not exceed $60 \mathrm{~mm}$ in any of the 52 years analyzed. 1993 and 1998 stood out once again because they presented the lowest accumulated rainfall in one day. The analysis of the Rx5day index revealed that the maximum value of concentrated precipitation in 5 consecutive days almost reached $150 \mathrm{~mm}$ in many years, especially in the first half of the data series analyzed. The highest rainfall peaks were in 1974, which, as indicated in the PRCPTOT calculations, was one of the years with the greatest annual precipitation.

The climate extremes indices R95p and R99p, which correspond to wet and extremely wet days, presented statistical significance in only two and one municipalities, respectively. Therefore, they were not considered in this analysis, since the study area presented, in previous indices, a trend in rainfall scarcity and gradual precipitation reduction, making the analysis of wet days ineffective for the present investigation.

\section{Conclusions}

The climate index results indicate a precipitation pattern change in the Pajeú river basin, given the homogeneity of the trends presented.

The decrease in total annual precipitation, in addition to the rise in consecutive dry days, corroborates other indices, showing signs of increased water scarcity in the region. These answers contribute to studies of recurrent droughts that progressively affect the semi-arid region of the Brazilian Northeast.

This projection of increased water scarcity points to a trend in greater demand for water use and conflicts in the basin, as the basin water is widely used for irrigation.

In this context, implementing public policies that promote strategies for reducing these conflicts and ensure regional sustainability is crucial. This analysis and the methodology applied can be extended and used in other river basins with similar characteristics.

\section{Contribution of authors:}

Assis, J.M.O.: Conceptualization, Methodology, Validation, Formal analysis, Investigation, Resources, Data curation, Writing - original draft. Menezes, A.F.: Cartography, Validation, Formal analysis, Writing — original draft. Souza, W.M.: Methodology, Formal analysis, Supervision. Sobral, M.C.: Methodology, Validation, Formal analysis, Investigation, Supervision, Visualization.

\section{References}

Agência Nacional de Águas (ANA). 2021. HidroWeb: sistemas de informações hidrológicas. ANA (Accessed August 2021) at: http://hidroweb.ana.gov.br/ HidroWeb.

Agência Pernambucana de Águas e Clima (APAC). Sistema de meteorologia e monitoramento. APAC (Accessed August 2021) at: http://old.apac.pe.gov.br/ meteorologia/monitoramento-pluvio.php.
Assis, J.M.O., 2016. Variabilidade do clima e cenários futuros de mudanças climáticas no trecho submédio da bacia hidrográfica do rio São Francisco. Tese de Doutorado, Programa de Pós-Graduação Engenharia Civil, Universidade Federal de Pernambuco, Recife.

Assis, J.M.O.; Souza, W.M.; Sobral, M.C., 2015. Análise Climática da Precipitação no Submédio da Bacia do Rio São Francisco com Base no Índice 
de Anomalia de Chuva. Revista Brasileira de Ciências Ambientais (Online), (36), 115-117. https://doi.org/10.5327/Z2176-947820151012.

Bork, C.K.; Castro, A.S.; Leandro, D.; Corrêa, L.B.; Siqueira, T.M., 2017. Índices de precipitação extrema para os períodos atual (1961-1990) e futuro (2011-2100) na bacia do rio Taquari-Antas, RS. Revista Brasileira de Ciências Ambientais (Online), (46), 29-45. https://doi.org/10.5327/Z2176947820170233.

Cardoso, A.S.; Alves, E.A.; Marques, E.A.T.; Castro, C.M.V.A.; Casé, M.; Sobral, M.C.M., 2019. Avaliação da toxicidade de piscicultura do semiárido de Pernambuco (Brasil). Brazilian Journal of Development, v. 5, (11), 2493424961. https://doi.org/10.34117/bjdv5n11-171.

Castro, C.A.C., 2002. Interações trópicos-extratrópicos na escala de tempo intrasazonal durante o verão austral e seus efeitos na América do Sul. Dissertação de Mestrado, Instituto Nacional de Pesquisas Espaciais, São Paulo.

Cavalcante Junior, E.G.; Medeiros, J.F.; Espínola Sobrinho, J.; Figueirêdo, V.B.; Costa, P.N.; Santos, W.O., 2016. Development and Water Requirements of Cowpea Under Climate Change Conditions in the Brazilian Semi-Arid Region. Revista Brasileira de Engenharia Agrícola e Ambiental, v. 20, (9), 783788. http://dx.doi.org/10.1590/1807-1929/agriambi.v20n9p783-788.

Galvão, M.L.M.; Santos, M.A.; Silva, F.N.; Silva, V.P., 2020. Connections Between Wind Energy, Poverty and Social Sustainability in Brazil's Semiarid. Sustainability, v. 12, (3), 864. http://dx.doi.org/10.3390/su12030864.

Grassi, B.; Redaelli, G.; Visconti, G., 2013. Arctic Sea Ice Reduction and Extreme Climate Events over the Mediterranean Region. Journal of Climate, v. 26, 10101-10110. https://doi.org/10.1175/JCLI-D-12-00697.1.

Huang, J.; Ji, M.; Xie, Y.; Wang, S.; He, Y.; Ran, J., 2016. Global semi-arid climate change over last 60 years. Climate Dynamics, (46), 1131-1150. https:// doi.org/10.1007/s00382-015-2636-8.

Intergovernmental Panel on Climate Change (IPCC), 2014. Climate Change 2014: Synthesis Report. Contribution of Working Groups I, II and III to the Fifth Assessment Report of the Intergovernmental Panel on Climate Change. IPCC, Geneva, Switzerland, $151 \mathrm{pp}$.

Kayano, M.T.; Kousky, V.E., 1996. Tropical circulation variability with emphasis on interannual and intraseasonal time scales. Revista Brasileira de Meteorologia, v. 11, (1-2), 6-17.

Kousky, V.; Kayano, M.T., 1994. Principal modes of outgoing longwave radiation and 250-mb circulation for the South American sector. Journal of Climate, v. 7, (7), 1131-1143. https://doi.org/10.1175/15200442(1994)007\%3C1131:PMOOLR\%3E2.0.CO;2.

Lemos, J.J.S.; Santiago, F.D., 2020. Instabilidade temporal na produção agrícola familiar de sequeiro no semiárido do nordeste brasileiro. Desenvolvimento em Questão, v. 18, (50), 186-200. https://doi. org/10.21527/2237-6453.2020.50.186-200.

Marengo, J.A.; Alves, L.M.; Alvala, R.C.S.; Cunha, A.P.; Brito, S.; Moraes, O.L.L., 2018. Climate Characteristics of the 2010-2016 Drought in The Semiarid Northeast Brazil Region. Anais da Academia Brasileira de Ciências, v. 90, (2 Supl. 1), 1678-2690. https://doi.org/10.1590/0001-3765201720170206.

Moncunill, D.F., 2006. The rainfalltrend over Ceará and its implications. In: $8^{\mathrm{a}}$ Conferência Internacional de Meteorologia e Oceanografia do Hemisfério Sul, Foz do Iguaçu. Anais... pp. 315-323.

Montenegro, S.G.; Montenegro, A.; Ragab, R., 2010. Improving agricultural water management in the semiarid region of Brazil: experimental and modelling study. Irrigation Science, v. 28, 301-316. https://doi.org/10.1007/ s00271-009-0191-y.
Nobre, P.; Pereira, E.B.; Lacerda, F.F.; Bursztyn, M.; Haddad, E.A.; Ley, D., 2019. Solar smart grid as a path to economic inclusion and adaptations to climate change in the Brazilian semiarid Northeast. International Journal of Climate Change Strategies and Management, v. 11, (4), 499-517. https://doi. org/10.1108/ijccsm-09-2018-0067.

Nóbrega, R.S.; Farias, R.F.L.; Santos, C.A.C., 2015. Variabilidade temporal e espacial da precipitação pluviométrica em Pernambuco através de índices de extremos climáticos. Revista Brasileira de Meteorologia, v. 30, (2), 171-180. https://doi.org/10.1590/0102-778620130624.

Nóbrega, S.N., 2010. Modelagem climática no Nordeste do Brasil: cenários e incertezas. In: Galvíncio, J.D.; Silva, D.F.; Nóbrega, S.N. (Eds.), Mudanças climáticas e recursos hídricos: aplicações no estado de Pernambuco. Ed. Universitária da UFPE, Recife, pp. 1-25.

Painel Brasileiro de Mudanças Climáticas - PBMC. 2013. Sumário Executivo do GT2. In: Ambrizzi, T.; Araujo, M. (Eds.), Primeiro Relatório de Avaliação Nacional do Painel Brasileiro de Mudanças Climáticas. Rio de Janeiro, PBMC.

Painel Brasileiro de Mudanças Climáticas - PBMC. 2014. Base científica das mudanças climáticas. In: Ambrizzi, T.; Araujo, M. (Eds.), Primeiro Relatório da Avaliação Nacional sobre Mudanças Climáticas. COPPE, Universidade Federal do Rio de Janeiro, Rio de Janeiro, 464 pp, pp. 25-63.

Pernambuco. 2006. Atlas de bacias hidrográficas de Pernambuco. Secretaria de Ciência, Tecnologia e Meio Ambiente, Recife.

RClimDex, 2004. Manual del usuario (Accessed June 2021) at: http://etccdi. pacificclimate.org/software.shtml.

Santos, C.A.S.; Rocha, F.A.; Ramos, T.B.; Alves, L.M.; Mateus, M.; Oliveira, R.P.; Neves, R., 2019. Using a hidrologic model to asses the performance of regional climate models in a semi-arid watershed in Brazil. Water, v. 11, (1), 170. https://doi.org/10.3390/w11010170.

Selvey, L.A.; Rutherford, S.; Dodds, J.; Dwyer, S.; Robinson, S.M., 2014. The impact of climate-related extreme events on public health workforce and infrastructure - how can we be better prepared? Australian and New Zealand Journal of Public Health, v. 38, (3), 208-210. https://doi.org/10.1111/17536405.12219 .

Silva, D.F.S.; Sousa, A.B., 2013. Deteç̧ão de tendências climáticas no estado de Alagoas. Revista Brasileira de Geografia Física, v. 6, (3), 442-455. https://doi. org/10.26848/rbgf.v6.3.p442-455.

Silva, G.B.; Souza, W.M.; Azevedo, P.V., 2012. Cenários de mudanças climáticas no estado da Bahia através de estudos numéricos e estatísticos. Revista Brasileira de Geografia Física, v. 5, (5), 1019-1034. https://doi.org/10.26848/ rbgf.v5i5.232891

Silva, G.K.; Silveira, C.; Silva, M.; Marcos Júnior, A.; Souza Filho, F.; Guimarães, S., 2020. Análise de projeções das mudanças climáticas sobre precipitação e temperatura nas regiões hidrográficas brasileiras para o século XXI. Revista Brasileira de Ciências Ambientais (Online), 1-17. http://dx.doi. org/10.5327/Z2176-947820200624.

Sobral, M.C.; Assis, J.M.O.; Oliveira, C.R.; Silva, G.M.N.; Morais, M.; Carvalho, R.M.C., 2018. Impacto das mudanças climáticas nos recursos hídricos no submédio da bacia hidrográfica do Rio São Francisco - Brasil. Revista Eletrônica do PRODEMA, v. 12, (3), 95-106. https://doi.org/10.22411/ rede2018.1203.10.

Souza, A.G.S.S.; Ribeiro Neto, A.; Rossato, L.; Alvalá, R.C.S.; Souza, L.L., 2018. Use of SMOS L3 Soil Moisture Data: Validation and Drought Assessment for Pernambuco State, Northeast Brazil. Remote Sensing, v. 10, (8), 1314. https:// doi.org/10.3390/rs10081314 
Vargas-Amelin, E.; Pindado, P., 2014. The challenge of climate change in Spain: Water resources, agriculture and land. Journal of Hydrology, v. 518, (parte B), 243-249. https://doi.org/10.1016/j.jhydrol.2013.11.035.

Viola, M.R.; Mello, C.R.; Pinto, D.B.F.; Mello, J.M.; Ávila, L.F., 2010. Métodos de interpolação espacial para o mapeamento da precipitação pluvial. Revista Brasileira de Engenharia Agrícola e Ambiental, v. 14, (9), 970-978. https://doi. org/10.1590/S1415-43662010000900009.
Yilmaz, A.G.; Hossain, I.; Perera, B.J.C., 2014. Effect of climate change and variability on extreme rainfall intensity-frequency-duration relationships: a case study of Melbourne. Hydrology and Earth System Sciences, v. 18, (10), 4065-4076. https://doi.org/10.5194/hess-18-4065-2014.

Zhang, Y.; Wang, J.C.; Jing, J.H.; Sun, J.C., 2014. Response of groundwater to climate change under extreme climate conditions in North China Plain. Journal of Earth Science, v. 25, 612-618. https://doi.org/10.1007/s12583-014-0443-5. 